\author{
IMAGE \\ UNAVAILABLE FOR \\ COPYRIGHT \\ REASONS
}

Just add salt: At Koor Foods' research station in Eilat, near the Red Sea, microalgae are cultivated in outdoor saltwater ponds.

\title{
MARINE BIOTECH IN THE NEGEV DESERT
}

\section{by Jonathan Weiner}

1

Tresh water is scarce in Israel's Negev desert. There is however, plenty of saltwater nearby, not only in the Mediterranean and Red Seas, but in aquifers deep below the desert's surface. Israeli scientists are thus on the lookout for saltwater organisms that produce useful chemicals; growing such organisms in artificial ponds would be one way of "farming" the desert.

One of the most salt-tolerant eukaryotic organisms known is a singlecelled algae called Dunaliella; it lives in, among other places, the supposedly lifeless waters of the Dead Sea which contain 29 percent salt. Weizmann Institute researchers Mordechai Avron and Ami Ben-Amotz have found that these algae keep their internal salt concentration far lower than that of the briny waters around it by synthesizing glycerol. Besides glycerol-an important industrial chemical-Dunaliella also makes $\beta$ carotene, also known as pro-vitamin A. The commercial potential of these products has led an Israeli firm, Koor Foods, to spend $\$ 2.5$ million over the last six years in developing outdoor Dunaliella cultivation and processing techniques. At Koor's research station in Eilat, Dunaliella bardawilli (a species found in the Sinai peninsula) is grown in artificial ponds; to maximize glycerol synthesis, the ponds are filled with seawater to which extra salt has been added. The algae are har- vested by centrifugation, a step whose expense has apparently led Koor to conclude that, near-term, glycerol production is not profitable.

$\beta$-carotene production looks more promising. Koor foresees marketing the substance as a health food and perhaps as a vitamin A substitute in animal feed. An American firm, Microbio Corp., has already begun producing $\beta$-carotene using the KoorAvron technology; a licensing agreement is under negotiation.

Carageenan and agar, used in foods as emulsifiers, gelling agents, and stabilizers, are derived from seaweed. The ecological damage done by overharvesting has led to a search for alternative sources. At the Institute of Applied Research at Ben-Gurion University (Beersheva, Israel), Shoshana Arad and co-workers have extracted a carageenan-like polysaccharide from a marine microalgae, Porphyridium, which is cultivated in outdoor saltwater ponds. Potential applications in food processing and other industries are being studied in the project, which is sponsored by Israel Chemicals Ltd.

Arad's group is also involved in a U.S. Department of Energy effort to grow oil-producing algae. The algae-Isochrysis and Nanochloropsisare being grown in outdoor saline ponds in the southwest U.S. Like the Negev, this region has underground sources of brackish water. The Israeli contribution to the project centers on outdoor algae cultivation, harvesting and processing techniques.

Algae are also used to improve the efficiency of solar energy collecting systems. Heated by the sun's rays, a "solar pond" can reach $65^{\circ} \mathrm{C}$, storing energy which is later transformed to electricity by a special turbine. Bacterial overgrowth in the pond's saline water can block sunlight, thereby reducing efficiency. In research sponsored by Ormat Turbines Ltd., which pioneered the solar pond, Moshe Shilo of Hebrew University developed an algae-produced "bio-flocculant" that causes water-clouding particles to clump together and sink. Shilo thinks the bioflocculant could also be used in purifying industrial effluents, and is seeking additional corporate sponsorship.

Petroferm Inc. (Amelia Island, FL) is commercializing an oil-emulsifying "bio-detergent" developed by three Tel Aviv University researchers. The company sees uses for the substance, called Emulsan, in enhanced oil recovery and pollution control. Eugene Rosenberg, David Gutnick, and their co-workers at Tel Aviv University first isolated Emulsan from a marine bacterium, Acinetobacter calcoaceticus, in the mid-1970s. More recently, Shilo has found a similar emulsifying agent, produced by a cyanobacterium. He foresees applications in the food industry, as well as in enhanced oil recovery.

For a free copy of this article (while available), write in 505 on Reader Service Card 